Spurlock, R.S. (2011) Cromwell's Edinburgh press and the development of print culture in Scotland. Scottish Historical Review, 90 (230). pp. 179-203. ISSN 0036-9241

Copyright (C) 2011 Edinburgh University Press

A copy can be downloaded for personal non-commercial research or study, without prior permission or charge

Content must not be changed in any way or reproduced in any format or medium without the formal permission of the copyright holder(s)

When referring to this work, full bibliographic details must be given

http://eprints.gla.ac.uk/84397

Deposited on: 14 August 2013

Enlighten - Research publications by members of the University of Glasgow http://eprints.gla.ac.uk 


\title{
Cromwell's Edinburgh Press and the Development of Print Culture in Scotland
}

\section{ABSTRACT}

\begin{abstract}
Alasdair Mann, the noted scholar of book culture in early modern Scotland, has suggested that a significant change had occurred in Scotland's relationship with the printed word by the late seventeenth century. This study sets out to explain how the interregnum served as a 'watershed' during which a consumer demand was created for popular print and how this in turn necessitated a significant increase in the production and distribution of printed material. Beginning with the sale of the press and patent of Evan Tyler to the London Stationers' Company in 1647, the article charts the key factors that transformed Scotland's printing industry from the production of official declarations and works for foreign markets to the production of polemical texts for a Scottish audience. These developments also witnessed publication of the first serial news journal and the growth of a competitive market for up-todate printed news. More than just an anomaly that flourished during a decade of occupation, these fundamental changes altered Scotland by introducing the large-scale consumption of chapbooks and printed ephemera, thereby initiating the nation's enduring print culture.
\end{abstract}

The impact of the mid-seventeenth-century interregnum has re-emerged in recent years as a vibrant topic of study, stimulating a prodigious quantity of publication. Sometimes dismissed as revisionist, this development has witnessed a reassessment of nationalistic, and sometimes xenophobic, explanations that have traditionally condemned the 1650 s as an anomalous decade, after which history reverted to its previously predetermined course. ${ }^{1}$ Macro studies,

${ }^{1}$ Rather than a simple story of foreign occupation, recent studies have demonstrated that Irish and Scots served the interregnum regimes within their own nations. See Micheál Ó Siochrú, God's Executioner: Oliver Cromwell and the Conquest of Ireland (London, 2008), 204-10; R. S. Spurlock, Cromwell and Scotland: Conquest and Religion, 1650-1660 (Edinburgh, 2007), 44. Traditional histories that have delineated the conflicts of the $1640 \mathrm{~s}$ and $1650 \mathrm{~s}$ in purely political, national and religious terms have missed the ideological, confessional and economic complexities of identity. For a

R. SCOTT SPURLOCK is Lecturer in Church History and Historical Theology, in the Institute of Theology, Queen's University Belfast. He would like to thank Dr Crawford Gribben for commenting upon an early version of this article. 
such as Patrick Little's edited collection The Cromwellian Protectorate, have encouraged fresh analysis of the impact which Commonwealth and Protectoral policies had in the 'peripheries' of Wales, Ireland and Scotland. ${ }^{2}$ Meanwhile, studies of individual participants in the unfolding political events have highlighted the interrelated networks of the interregnum governments, as well as clarifying the regionally distinctive approaches by which centralised directives were to be achieved, demonstrating that allegiances depended on changing localised contexts. ${ }^{3}$ Such work has in turn prompted greater analysis of the 'peripheries' and the specific impact of Cromwellian policies upon them, thereby challenging many misconceptions and demonstrating the lasting legacy of the interregnum on these areas. ${ }^{4}$ The result is that the period is increasingly viewed as an integral part of the history of all three nations, as well as being an era in which lasting political and cultural changes were effected.

This study will address one aspect of cultural change. Alastair J. Mann has argued that a significant shift had occurred in Scottish society by the end of the seventeenth century. An increasing interest emerged, he has argued, in 'the polite engagement with book culture and leisure'. The 1650s were crucial to this cultural development of the Restoration era, which witnessed a doubling of the number of book traders between 1660 and $1680 .{ }^{5}$ The present study seeks to explain how this fundamental shift, theorised by Mann, took place in practice. It begins to explain why the interregnum coincided with what Mann has called a "watershed - the start of an historical "gear change" where book culture and literacy expanded at a rapid and accelerating speed' ${ }^{6}$

Although pre-interregnum Scotland hosted a handful of printing houses, the industry was dominated by the three presses of the Edinburgh-based print house of Evan Tyler. Tyler, an Englishman, seems to have had few loyalties. Appointed in 1641, jointly with Robert Young, as the King's Printer in Scotland, Tyler continued to publish for both king and Kirk until the beginning of September $1650 .^{7}$ Upon the very day of Cromwell's arrival in Edinburgh Tyler's

${ }^{1}$ (Continued) broader assessment of identity in the English theatre of the British Civil Wars, see Mark Stoyle, Soldiers and Strangers: An Ethnic History of the English Civil War (New Haven, 2005).

2 Patrick Little (ed.), The Cromwellian Protectorate (Woodbridge, 2007).

3 See, for instance, Patrick Little (ed.), Lord Broghill and the Cromwellian Union with Ireland and Scotland (Woodbridge, 2004); D. L. Smith and Patrick Little (eds), Parliaments and Politics during the Cromwellian Protectorate (Cambridge, 2007).

${ }^{4}$ Crawford Gribben, God's Irishmen: Theological Debates in Cromwellian Ireland (Oxford, 2007); Ó Siochrú, God's Executioner; Spurlock, Cromwell and Scotland.

5 A. J. Mann, The Scottish Book Trade, 1500-1720: Print Commerce and Print Control in Early Modern Scotland (East Linton, 2000), 31.

6 Ibid., 33.

7 Young died in 1643, leaving Tyler sole holder of the grant. David Stevenson, 'A revolutionary regime and the press: the Scottish Covenanters and their printers, 1638-51', in idem, Union, Revolution and Religion in Seventeenth-Century Scotland, XV (Aldershot, 1997) [Stevenson, 'Revolutionary regime'], 326. 
imprint also appeared on pro-Commonwealth publications of both a secular and religious nature. While this might suggest Tyler's politics changed overnight, the situation is more complicated when it is explained that Evan Tyler was not just an individual, but also the 'brand' used by the London-based Stationers' Company (which controlled the printing industry in England) for its printing endeavours in Scotland.

The fate of Evan Tyler's presses had traditionally baffled historians. It had been supposed ever since 1713 that his presses were sold to the Stationers' Company sometime after the English conquest of Edinburgh. ${ }^{8}$ W. J. Couper claimed that Evan Tyler left Scotland in 1650, returning to Edinburgh only in 1651 and 1652. Although incorrect, Couper came close to solving the problem when noting a report that the Stationers' Company had purchased a Scottish printing shop for 'a great sum' in $1647 .{ }^{9}$ Although non-committal as to whether this acquisition was the printing house of Evan Tyler, Couper was on track to unravelling a truth which dramatically reshaped traditional understandings about the use of the printing press in interregnum Scotland.

It was eventually David Stevenson who resolved the conundrum although the facts are also spelled out in the Calendar of State Papers for February $1651 .{ }^{10}$ The Stationers' Society purchased the rights to the company and the equipment of Evan Tyler’s Edinburgh shop for $£ 430$ sterling in $1647 .{ }^{11}$ The transaction was motivated by Tyler's possession of the royal patent in Scotland. The patent, Stevenson explained, gave Tyler 'the rights of the King's Printer to export to England and thus evade monopoly restrictions'. ${ }^{12}$ By buying out Tyler's name and patent, the Stationers' Company had purchased a significant share of the Scottish market. More importantly, it had also acquired control of the lucrative, backdoor access to English markets that were available to the king's Scottish printer, who was exempt from English patents. ${ }^{13}$

8 James Watson, James Watson's Preface to the History of Printing 1713 (Greenock, 1963), 8; George Chalmers, An Historical Account of Printing in Scotland during Two Centuries... 1507 to 1707, 2 vols (Edinburgh, National Library of Scotland [NLS], MS Adv. 17.1.16) i. fo. 186); George Chalmers, The Life of Thomas Ruddiman, A.M. (London, 1794), 117; James Chalmers, An Historical Account of Printing in Scotland from 1507 to 1707 Containing Anecdotes of the Printers with Their Works and the Several Patents to the Kings Printers, 2 vols (NLS, MS. Adv. 16.2.21), i. fo. 287; H. G. Aldis, List of Books Printed in Scotland Before 1700 (Edinburgh, 1970), 114.

${ }^{9}$ W. J. Couper, Scottish Rebel Printers (Edinburgh, 1912), 9-15.

10 Stevenson, 'Revolutionary regime', 315-37; M. A. E. Green (ed.), Calendar of State Papers, Domestic Series, 1651-1660 [CSPD], 1651, 65.

11 Stevenson, 'Revolutionary regime', 327; A. J. Mann, "Some property is theft": copyright law and illegal activity in early modern Scotland', in Robin Myers, Michael Harris and Giles Mandelbrote (eds), Against the Law: Crime, Sharp Practice and the Control of Print (London, 2004), 31-60, 34; Cyprian Blagden, The Stationers' Company: A History, 1403-1959 (London, 1960), 142; Robin Myers, The Stationers' Company Archive, 1554-1984 (Winchester and Detroit, 1990), 5.

12 Stevenson, 'Revolutionary regime', 326.

13 Blagden, Stationers' Company, 142. 
This was a significant issue because throughout the later 1630s and 1640s Scottish printing was primarily producing for foreign markets, England in particular. ${ }^{14}$ Hence, the printing presses of 'Evan Tyler' were controlled from London for nearly three years before Cromwell invaded Scotland though whether Tyler continued to have a role in the enterprise is not clear. In 1649 Tyler or the new stakeholders petitioned the Committee of Estates for back-pay accumulated over eight years. The resolution of the Committee included some remnants of the original petition in which it was claimed that sums resulting from both a promised stipend and a fee per sheet printed, were still owed to Tyler, for his faithful and diligent service

continually printing such things as issued from his majesty and from parliaments, conventions, committees of estate and committee of excise and other committees of parliament, lords of secret council and other public judicatories, working on occasion of some extraordinary affairs both night and day and always supporting a greater number of servants upon daily wages than ordinary, with three presses to attend their service. ${ }^{15}$

Whether Tyler drafted the petition personally or whether it was drawn up in his name by the Stationers' Society remains unclear. In either case, it confirms the patent holder's lucrative monopoly on government publishing.

Since the motives of the London-based owners were purely financial, the print house continued to publish for Kirk and king through the contentious years during and after the Second English Civil War. They probably had little option as the patent, along with its privileges, carried responsibilities to provide a service to government. Moreover, given the limited freedom extended to the press between 1647 and 1650, there was slight opportunity to print other material. ${ }^{16}$ The Covenanters maintained a tight reign over both the religious and political life of the nation. After the National Covenant had been signed in 1638 the power of censorship fell to the General Assembly of the Church of Scotland. ${ }^{17}$ From December all publications referring to the Kirk or

14 Arthur Williamson, 'Scotland: international politics, international press', in S. A. Baron, E. N. Lindquist and E. F. Shevlin (eds), Agent of Change (Amherst, 2007), 193-215; Joad Raymond, Pamphlets and Pamphleteering in Early Modern Britain (Cambridge and New York, 2007), 161-201.

15 Edinburgh, National Records of Scotland [NRS], PA2/24, fo. 245.

${ }^{16}$ In March 1648 the man running Tyler's press, John Twyn, was called before parliament to answer for printing a declaration of the Commissioners of the General Assembly. Asked on whose authority this had been done, Twyne 'declared that he had warrant from $\mathrm{Mr}$ Andrew Kerr, clerk to the general assembly of the church'. After producing his warrant for inspection, it was returned (NRS, PA2/24, fo. 6v.). This incident demonstrates the strict control that was exerted over printing under the Covenanter's government.

17 During the previous two decades authority over the print industry had been the prerogative of the Privy Council. For its exercise of this power, see Mann, 'Some property is theft', 36 . 
religion required pre-publication approval from Sir Archibald Johnston of Wariston, the clerk of the Assembly and advocate for the Kirk. These censures were reaffirmed in 1643 and $1647 .{ }^{18}$ Meanwhile, the Committee of Estates also moved to assert control of printed materials. In February 1646 it ordained

that in all well governed kingdoms it is expressly prohibited that any subject take upon hand to print or publish books of whatsoever discipline or science, but especially libels or chronicles concerning the state of the kingdom or ages past, without warrant or allowance for that effect, therefore the committee of estates, according to the practice of the convention of estates in former times, statute and ordain that no persons of whatsoever rank, degree or calling take upon hand to print, publish or set out any manner of book, libel, history or other paper; as also that no book being printed out of the kingdom be brought in and sold within the same until first they be seen and revised by his majesty's secretary. ${ }^{19}$

During the Engagement Crisis (1647-8) the Committee reasserted the severity with which it intended to enforce censorship by pronouncing the death penalty for printers of unauthorised publications. ${ }^{20}$ Yet the situation would change significantly from September 1650.

In all likelihood Tyler was not in Edinburgh on Cromwell's arrival in 1650. Contemporary reports suggest that since at least 1648 an Englishman, John Twyn, had been running the presses, along with seven English servants. ${ }^{21} \mathrm{~A}$ list of those exempted from the Scottish levy of July 1650 was noted in the burgh records of Edinburgh and it included eight printers described as both English and printers to the king. ${ }^{22}$ Tyler's name is not among them. 'Evan Tyler' remained the imprint of the printing house until it changed to Christopher Higgins in 1655 . The policy of maintaining the imprint was, according to David Stevenson, because of growing international pressures:

At a time when relations between the kingdoms were frequently strained and sometimes led to war, for the [London Stationers'] Company to have advertised through its imprint its ownership of the Scottish state printer could have led in Scotland to demands for a Scottish take-over, and in

${ }^{18}$ Church of Scotland: General Assembly, Acts of the General Assembly of the Church of Scotland, 1638-1842, ed. T. Pitcairn (Edinburgh, 1843), 30, 75-6, 160.

19 NRS, PA2/23, fo. $347 \mathrm{r}$.

${ }^{20}$ Reference to the Committee of Estates passing an act 'discharging printing under pain of death of 16 June [1648]', is made in a decree of 10 March 1649 against Sir Archibald Primrose, clerk of secret council (NRS, PA2/24, fos 193r-94v).

${ }^{21}$ Stevenson, 'Revolutionary regime', 333. Tyler's absence when Cromwell arrived in Edinburgh is suggested by his resumption of printing for the king at the Restoration. It is difficult to see how this could have happened unless Tyler pleaded that during his absence he had no control over what was produced under his imprint. Twyn was appointed to run the press by the Stationers' Company after the death of Thomas Pape in 1647 (Blagden, Stationers' Company, 142).

22 Marguerite Wood (ed.), Extracts from the Records of the Burgh of Edinburgh, 1642 to 1655 (Edinburgh, 1938), 252; Stevenson, 'Revolutionary regime', 333. 
England demands that the Company stop its Scottish branch printing anti-English propaganda. The problems of the multi-national company in times of international tension are nothing new! ${ }^{23}$

Although many historians believed that Higgins arrived sometime between 1651 and 1654, he was listed among the men already working at Tyler's presses in July $1650 .{ }^{24}$ It can, therefore, be asserted confidently that the printers who served the needs of king and Kirk before Cromwell's invasion provided identical services for the new regime throughout the interregnum. Yet, despite limitations on what could be printed, it seems that the Evan Tyler presses could not meet all of the production demands of the Stationers' Company in Edinburgh. In 1650 William Nisbet's $A$ Golden Chaine of Time was published by The Heirs of George Anderson 'for the Company of Stationers', an imprint that suggests the Society was hiring the services of a second print house..$^{25}$

It is nonetheless clear that upon arriving in Edinburgh the English had willing compliance from the most important print house in the country. It was used on their first day in the city to produce a proclamation permitting a much needed market day. Hence, one of the earliest acts of the new regime was to use the press as a means of conveying official information. By the end of 1650 the English regime was not, however, the only body in Scotland using a press. After Tyler's shop had begun to print for the English regime, the king declared on 4 December 1650 that Tyler's appointment as the royal printer was to be quashed:

[Tyler] not onlie maid his residence in England and joyned himself with that rebellious pairtie thaire who have rejected governement But also have joyned to that pairtie who have invaded this Kingdome and by himself and his servands printed and published diverse seditious rebellious and scandalous papers destructive to his Majesties Governement and to the Governement of this Kirk and Kingdome. ${ }^{26}$

The king chose the Edinburgh-based bookseller Duncan Mun as Tyler's replacement but Mun lacked an essential piece of equipment -a press - and so never delivered publications under his new patent. ${ }^{27}$ With

23 Ibid., 333

24 Ibid., 252

25 It has been suggested that some Edinburgh stationers formed a 'Society' for publishing works for their respective shops as early as 1649 (J. Chalmers, Historical Account of Printing, i. 320). There is, however, little evidence of this endeavour until the imprint appeared in 1660. According to Watson, the Stationers' Company made little profit after the Restoration and soon sold the press to a group of Scottish printers (Watson, Preface, 10). This remains uncertain.

26 Couper, Scottish Rebel Printers, 11-12. The document is printed in its entirety in James Maclehose, The Glasgow University Press, 1638-1931 (Glasgow, 1931), 32-4, while the original is located at NRS, Registrum Secreti Sigilli, vol. 116, fo. 179.

27 Maclehose, Glasgow University Press 33; Stevenson, 'Revolutionary regime', 334. 
Mun unable to print, another option had to be found urgently. There was a press in Aberdeen, far beyond the reach of the English south of Forth, belonging to James Brown. This was activated to advocate the cause of the king and the covenants, although the radical minority within the Kirk regarded support of the king as malignancy.

After the battle of Dunbar on 3 September 1650 the radical party of the Kirk fell out of favour with the moderate majority. ${ }^{28}$ The intense purge of the army at the behest of the more extreme party, and the army's subsequent route at Dunbar, weakened the radicals' position. ${ }^{29}$ The moderate group (which would later make up the Resolutioner party) acted as the Commissioners of the General Assembly (the Commissioners of 1651). ${ }^{30}$ In September 1650 they fell back from Edinburgh and began on James Brown's Aberdeen press to produce works which supported the covenants and the king, as well as declarations for fasting and polemical propaganda intended to steer the Kirk between what was identified as the "two Rocks of the Malignant Scylla and Sectarian Charybdis' ${ }^{31}$ The intention of the Commissioners to create propaganda is clear from the product of their presses but that this was at the forefront of their minds is supported by Robert Baillie's complaint made in May 1651: 'Your press is exceeding slow: I think, Mr Robert Ramsay's, and Mr James Fergusone's paper might have been printed; ${ }^{32}$ and some invitation to the English to leave Cromwell, whither

${ }^{28}$ For analysis of the Protester-Resolutioner conflict, see K. D. Holfelder, 'Factionalism in the Kirk during the Cromwellian Invasion and Occupation of Scotland, 1650 to 1660: the Protester-Resolutioner Controversy', unpublished Ph.D. thesis (University of Edinburgh, 1998) [Holfelder, 'Factionalism'].

29 David Stevenson, Revolution and Counter-Revolution in Scotland, 1644-1651 (London, 1977), 145; Spurlock, Cromwell and Scotland, 28-9, 35-8.

30 The Protesters also claimed to be the Commissioners of the General Assembly but styled themselves the '1650 Commissioners', referring to the General Assembly before the Public Resolutions, which they viewed as a corruption of the Kirk.

${ }^{31}$ Bulstrode Whitelocke, Memorials of the English Affairs, 4 vols (Oxford, 1853), ii. 447. Holfelder, 'Factionalism', 94-5 claims that the Resolutioners acquired Brown's services in response to Protester works printed on Tyler's press. This is chronologically incorrect since the pro-monarchy moderate party of the Kirk, which controlled the Commission of the General Assembly, printed several items on Brown's press in the closing months of 1650. Holfelder's assumption is probably based upon the Commissioners' complaint in early January 1651 that 'the wanting of a presse for printing doth exceedingly impeed the speedy dispatch of papers necessarie for information' and that Aberdeen had yet to receive some papers produced by the Commission (A. F. Mitchell and James Christie (eds), Records of the Commission of the General Assembly, 3 vols (Edinburgh, 1890-1909) [RCGA], iii. 251). The existence of Resolutioner works produced by Brown in late 1650 shows unequivocally that the printer was already active in their cause before the end of the year. Thus, the comments regarding 'want' in reference to printing probably refer to the isolation and slowness of the Aberdeen press in comparison to Tyler's, rather than an actual inability to find a printing press.

32 Possibly a prototype of A Brief Refutation of the Errors Toleration, Erastianism, Independency and Separation (London, 1692). Although this work was based on a collection of sermons preached by Fergusson in 1652, it may provide at least an insight into the content of an earlier work. 
many of them doe incline' ${ }^{33}$ Baillie was not the first moderate to lament that the press was not working fast enough. In February the moderate controlled Commission of the General Assembly sent John MacGhie, who had 'a care of printing the public papers', to Aberdeen to hasten the process. He was to pay the printer and ensure that works were distributed to the various presbyteries, while also protecting the press from the influences of the radical party in the Kirk: Andrew Cant was then a leading figure among the radicals and also minister in Aberdeen. To aid MacGhie a letter was sent to the provost of Aberdeen, requesting him to advance the money needed to complete the works. ${ }^{34}$

From their press in Aberdeen the moderate Commissioners of the General Assembly continued to attack the English as 'sectarians'. In A Solemn Warning to All the Members of This Kirk, produced on 7 January 1651 in Perth, the Commissioners explained that, despite apparent victory over Scotland, the English still bore great guilt for invading Scotland, for breaking the Solemn League and Covenant and for 'in subordination to Religion' ${ }^{35}$ The Commissioners encouraged the godly to persevere and further threatened the excommunication and censure of those Scots who aided the invaders. In March a second warning was produced, entitled $A$ Short Exhortation and Warning to the Ministers and Professours of This Kirk. This reiterated the message of the first, proclaiming the on-going responsibility of the Kirk to resist sectarians who made 'a strange noise in the midst of some Congregations'. ${ }^{36}$

From early in their campaign the English had recognised the growing tensions in the Kirk and they hoped to take advantage of these divisions. ${ }^{37}$ After the moderate majority started production on Brown's presses from late 1650, the English decided to publish works by the moderates' Presbyterian rivals - who would later become known as Protesters - in which the moderates were accused of malignancy. ${ }^{38}$ The first Remonstrant (or Protester) work to be printed by the Englishcontrolled presses of Evan Tyler was The Remonstrance of the Presbytery of Sterling. ${ }^{39}$ After its publication rumours circulated that the paper had been delivered to Cromwell by Archibald Johnston of Wariston,

33 Robert Baillie, Letters and Journals, ed. David Laing, 3 vols (Edinburgh, 1841-2), iii. 168.

${ }^{34} R C G A$, iii. 285-6.

35 Andrew Kerr, A Solemn Warning to all the Members of this Kirk, from the Commission of the Generall Assemblie with an Act for the censuring such as act, or comply with the Sectarian Armies (Aberdeen, 1651), 5.

36 Commission of the General Assembly, A Short Exhortation and Warning, to the Ministers and Professours of this Kirk, Perth, 20 March 1651 (Aberdeen, 1651), 1-3.

37 Frances Dow, Cromwellian Scotland, 1651-1660 (Edinburgh, 1979), 25-7.

38 Stevenson, 'Revolutionary regime', 335; Jason Peacey, Politicians and Pamphleteers: Propaganda during the English Civil Wars and Interregnum (Aldershot, 2004), 255.

39 Church of Scotland: Presbytery of Stirling, The Remonstrance of the Presbyterie of Sterling Against the Present Conjunction with the Malignant Party to the Commission of the Kirk at St. Johnston (Edinburgh, 1651). Submitted to the Commissioners of the General Assembly late in December 1650, the work was printed by the English in early February 1651 . 
an avid opponent to the resolutions with the king; Johnston was in Edinburgh meeting with the Lord General around the time it was printed. Although it is highly doubtful that Wariston delivered the paper to Cromwell, it is clear that when it came into Cromwell's hands he instructed that it be printed.$^{40}$ Meanwhile, the rumours that some were colluding with the English had exacerbated the distrust and division already evident among the Scots. From June 1650 it was alleged that some individuals were lukewarm in preparing to resist the impending English invasion. John Swinton, Sir John Chiesley, William Glendinning, Sir James Stewart (provost of Edinburgh), John Jaffray and Sir James Hope of Hopetoun had all voted against the levy of troops, even although an English invasion was highly likely. ${ }^{41}$ In November Hope of Hopetoun was accused of treating with Cromwell and acting as 'a maine plotter and contriuer, assister and abbaitter of all the mischief that hes befallen the kingdome'; and similar accusations were levelled against the ministers James Guthrie and Patrick Gillespie. ${ }^{42}$ By December several Scots, including Colonel Archibald Strachan and John Swinton, had joined the English. Suspicion of treason reached its height in January, when the three Hope brothers (John of Craighall, James of Hopetoun and Alexander) met with the king and proposed that he abandon his claims to England and Ireland, make peace with Cromwell, relinquish those areas already under English control and surrender several Scottish towns and strongholds as security. ${ }^{43}$ Such events intensified fears and increased division among the Scots, precisely what Cromwell and his regime had hoped for when printing The Remonstrance. ${ }^{44}$

The radical party's access to the English-controlled printing presses in Edinburgh had a significant impact on radical-moderate relations within the Kirk and prompted a marked change in the moderate party's polemics. Tensions continued to build until the General Assembly met in July 1651, the outcome of which was the polarisation of radical and moderate opinion into the Protester and Resolutioner parties. This schism was to last until the Restoration and it may be argued that these divisions, caused by the quest to interpret the obligations placed upon Scotland by the covenants, were so deep that they could

${ }^{40}$ William Row, The Life of Mr Robert Blair, ed. Thomas McCrie, Wodrow Soc. (Edinburgh, 1848), 256; Holfelder, 'Factionalism', 93-4.

${ }^{41}$ Sir James Balfour, The Historical Works of James Balfour of Denmylne and Kinnaird, Knight and Baronet; Lord Lyon King at Arms to Charles the First, and Charles the Second, 4 vols (Edinburgh, 1824), iv. 80.

42 Ibid., iv, 172-4; J. R. Young, The Scottish Parliament, 1639-1661: A Political and Constitutional Analysis (Edinburgh, 1996), 264.

43 Thomas Carte (ed.), Original Letters and Papers, Concerning the Affairs of England, From the Year 1641 to 1660, 2 vols (London, 1739), i. 410; Stevenson, Counter-Revolution, 164-5; Balfour, Historical Works, iv. 238-40, 246. For a fuller discussion of James Hope and his career during the interregnum, see A. H. Williamson, 'Union with England Traditional, union with England Radical: Sir James Hope and the mid-seventeenthcentury British state', English Historical Review, 110 (1995) 303-22.

${ }^{44}$ Stevenson, Counter-Revolution, 163. 
only have been healed by the re-emergence of the mutual enemy of Episcopacy and the persecution of Covenanters after the Restoration. Meanwhile, the Commissioners of the General Assembly had replied to the remonstration from Stirling with The Answer of the Commission of the Generall Assemblie. ${ }^{45}$ Several papers were, however, submitted in protest against the validity of the assembly because it upheld the king's place in the covenants and the inclusion of malignants in the Kirk. ${ }^{46}$ In August Robert Douglas, the moderator of the General Assembly, produced $A$ Short Information which was addressed to Presbyterians in England and implored them to beware of the Protesters. Douglas also defended the Resolutioners against accusations of malignancy, claiming that the Protesters' divisiveness was as dangerous as the sectarian army. They 'have opposed these just and necessary Resolutions, and actively obstructed the use of the lawfull and only likely means left of opposition to the prevailling Enemy... setting on foote a State-separation which necessarly tendeth to a Kirk-separation' ${ }^{47}$

Douglas' Short Information was the last paper produced on a free Scottish press. Less than a month after its publication Aberdeen surrendered to General Monck and Brown's press was silenced, leaving the English in complete control of Scotland's printing industry. They nonetheless regularly allowed material produced by both the Protesters and the Resolutioners to be published: infighting within the Kirk served to weaken Scottish resistance and to diminish Presbyterian interference in the pursuit of a religiously tolerant Republican commonwealth. ${ }^{48}$ In October 1651 the English published a Protester work, entitled A discovery after some search of the Sins of the Ministers... by the Brethren of the Presbytery of Kilmarnock. The English particularly enjoyed this paper because it offered an admission by some in the Kirk that they had been too concerned 'with their own credit and applause'. ${ }^{49}$ With absolute control of Scotland's presses the regime also began to attack the Kirk more overtly though it is interesting to note that the English printed only two polemical works against the king. ${ }^{50}$ The first, printed soon

45 Church of Scotland: General Assembly, Commission, The Answer of the Commission of the Generall Assemblie, to the quaeree, propounded to them, from the Parliament. With an answer of the Commission of the Generall Assemblie, to a letter, sent to them, from the ministers of the Presbyterie of Sterline... (Aberdeen, 1651).

46 The protestation of diverse ministers, against the proceedings of the late commission of the Church of Scotland: as also against the lawfulnesse of the present pretended assembly (Leith, 1651); Holfelder, 'Factionalism', 121-9.

47 Robert Douglas, Short Information. A Short Information and Brotherly Exhortation to Our Brethren of England: From the Commissioners of the Generall Assembly of the Kirk of Scotland Convened at Forfarr, August 12, 1651 (Aberdeen, 1651), 3.

48 For an assessment of Cromwellian policies towards the Church of Scotland, see Spurlock, Cromwell and Scotland, passim.

${ }^{49}$ Mercurius Politicus (21-8 Oct. 1651), 103; Presbytery of Kilmarnock, A discovery after some search of the Sins of the Ministers... by the Brethren of the Presbytery of Kilmarnock (Leith, 1651).

50 For a discussion of anti-Kirk propaganda, see Spurlock, Cromwell and Scotland, chapter 3 . 
after the battle of Dunbar, was entitled The King of Scotlands Negociations at Rome for Assistance Against the Common-Wealth of England and sought to alienate the 'papist' Charles II from the fervent Presbyterians who supported the Covenanters' position on monarchy. ${ }^{51}$ This edition included text from an earlier version printed in London as well as some additional letters taken at Dunbar and purportedly describing a Roman Catholic plot. Even in these polemics against monarchy, religion prevailed as a fundamental reason for opposing Charles II.

The other anti-monarchical work came shortly before the battle of Worcester in 1651 and was probably printed in Edinburgh in 1650 and again in $1651 .^{52}$ It proved to be the regime's last veiled attack on monarchy ${ }^{53}$ Craftily bestowed with a title suggesting a promonarchical stance, The Grounds and Reasons of Monarchy, Considered and Exemplified out of the Scottish History was actually a work of Cromwellian propaganda. ${ }^{54}$ Its title page ascribed authorship to 'J.H.', which subsequently led to erroneous conjecture that James Harrington, author of Oceana, was its writer. The actual author was the Cambridge graduate John Hall, who had accompanied Cromwell into Scotland in 1650 by order of the Council of State. Hall received a pension from the Council and was perhaps employed as a polemicist. ${ }^{55}$ In this tract he challenged the divine ordination of monarchy and the purity of monarchical succession in Scotland. He noted that Israel had demanded a king in order to be ruled as neighbouring nations were but, even although God had provided the Israelites with a king, monarchy was not God's perfect intention. ${ }^{56}$ Hall argued the Sanhedrin was the divinely ordained pattern of human government and that the Republicanism of the Commonwealth must be closer to such a form than to monarchy. He proceeded to argue that Charles I's dealings with popery and his marriage to a Catholic proved him to be a usurper. God had judged him for his usurpation and blasphemy. Scotland's blindness

51 The King of Scotlands Negociations at Rome for Assistance Against the Common-Wealth of England, As Also Severall Letters of the Chancellour of Scotland to the King Since His Coming Into Scotland, Taken in His Cabinet at the Late Fight Neer Dunbar (Edinburgh, 1650).

${ }^{52} \mathrm{~J}$. Chalmers, An Historical Account, i. fo. 284. An edition of the work was printed in 1650 in London with the imprint that it was reproduced from an Edinburgh copy. The first copy printed in Edinburgh has not survived.

53 In 1653 a work was published in Leith defending the Commonwealth [Peter English, The Survey of Policy or A Free Vindication of the Commonwealth of England, Against Salmasius and Other Royallists (Leith, 1653)], in which arguments were made against royalist opponents. English was commissioned for this work by Robert Lilburne and John Lambert (Oxford, Worcester College, Clarke MSS 3/6, fo. 1; Peacey, Politicians and Pamphleteers, 81, 183, 267). English's work was probably in response to Glencairn's rising which gathered pace in March of that year.

54 John Hall, The Grounds and Reasons of Monarchy, Considered and Exemplified Out of the Scottish History by J.H. (Edinburgh, 1651).

55 The paper is included in the complete works of Harrington: John Toland (ed.), The Oceana of James Harrington and his other works (London, 1700), xxxviii; J. Chalmers, An Historical Account, i. fo. 284.

561 Samuel 8 
to these truths had permitted the nation to deal with his son, which in turn brought punishment upon the country:

how dangerous it is to espouse such an interest, which God with so visible and severe a hand fights against, carryed on by, and for the support of a Tyrannizing Nobility and Clergy, and wherein the poor People are blindly led on by those affrighting (but false and ungrounded) pretensions of perfidy and perjury, and made instrumentall with their own estates and blood, for the enslaving and ruining themselves. ${ }^{57}$

In this attack upon Charles II the author continued to place equal blame on the 'tyrannising' nobility and clergy. He asserted that the Kirk's dealings with Charles II, along with its misguided pressing of both monarchy and Presbyterianism upon England under the guise of the covenants, were the cause of England's invasion of Scotland. The king had no divine right to rule and the Kirk's continued support for him in its covenants showed it had little understanding of how to interpret God's providence. Hence, blame for Scotland's suffering lay with the 'perfidy and perjury' of the nobility and clergy ${ }^{58}$

It is intriguing that the publications from the early days of the Cromwellian occupation broached topics which had never before been addressed by Scottish presses. Although Scottish Covenanters had condemned the tyrannical nature of Charles I, in documents distributed in England before the first Bishops' War, they had not questioned the legitimacy of monarchy itself. ${ }^{59}$ While the legitimacy of Episcopacy had been questioned, the entity of the national Kirk had not been queried. Moreover, although the press had been used to justify Presbyterianism and to demonise sectarian opponents, this occurred only briefly in Scotland, when, in the late 1630s, the Covenanters experimented with producing short, polemical works. George Gillespie had, for example, distilled his 350-page A Dispute Against the English-Popish Ceremonies, Obtruded upon the Church of Scotland (1637) into the four-page Reasons for which the Service Booke, Urged upon Scotland, Ought to be Refused (1638). ${ }^{60}$ Such endeavours had, however, come to an abrupt end once the Covenanters attained their domestic aims, though they continued to print for an English market (on Scottish, English and continental presses) in an effort to promote Presbyterianism in England. They did this so effectively that Joad Raymond has argued that Scots invented the virulent polemic that flowed throughout the 1640s in England ${ }^{61}$ Nevertheless, these polemics had little effect on Scotland before the interregnum because of censorship applied by the Covenanter government. The significance

\footnotetext{
57 Hall, Grounds and Reasons, 50.

58 Ibid., 50.

59 Stevenson, 'Revolutionary regime', 325.

60 Raymond, Pamphlets and Pamphleteering, 174-5.

61 Ibid., 171-92.
} 
of Commonwealth policy towards printing in Scotland was, therefore, twofold. First, the English regime utilised the press in a wholly novel fashion in Scotland. Traditional aspects of Scottish culture were directly challenged and religious, political and judicial alternatives were offered. Second, this led to a new atmosphere of public discourse about such issues. Importantly, discussion was not limited to print. Throughout the interregnum English soldiers challenged Scots to debate issues of religion, politics and the just nature of the English invasion of Scotland. ${ }^{62}$ To some extent developments in the realm of print culture echoed wider political developments identified by David Stevenson; that is, a Scottish export resulted in an unwanted import from England. ${ }^{63}$ Scotland's exportation of vitriolic and polemical print came home to roost in September 1650 because the English regime believed open dialogue to be integral to a Republican commonwealth.

In a pamphlet produced on the press carried in his military train before crossing the Tweed, Cromwell identified the enemy in Scotland as the political structure of monarchy and the religiously oppressive Kirk. 'The Gentry and Commonalty of ... Scotland...,' he wrote, 'are not the Persons, who... laid the certain foundations of a second unrighteous and unjust Invasion of England'. ${ }^{64}$ The English intended to neutralise the ideological stranglehold which monarchy and Presbyterianism exercised over the Scottish population and to implement changes which would allow for Scotland to be smoothly integrated into the Commonwealth. The English supposed their cause would awaken dormant desires for drastic social and religious change in Scotland and that, given the opportunity, the Scottish masses would seek liberation from their political and religious oppression. Ideological alterations were integral to the process of creating a union and in order to achieve these changes, a new culture of discourse and public debate was to be introduced. ${ }^{65}$ Traditionally decisions pertaining to the political and ecclesiastical structure of Scotland had been made by a narrowly-based establishment, comprising the monarchy, parliament, the General Assembly of the Church of Scotland and bodies which derived their authority from one of these institutions, such as the Privy Council, the Committee of Estates or commissions of the General Assembly. Even the debate regarding Episcopacy earlier in the decade had been largely conducted behind the closed doors of these institutions. Moreover, whereas the subscription of the National Covenant in 1638 had sought to create religious uniformity, the Commonwealth now presented its cause as the defence of religious freedom, toleration and a protestant diversity which allowed for the open reading of God's providential dispensations.

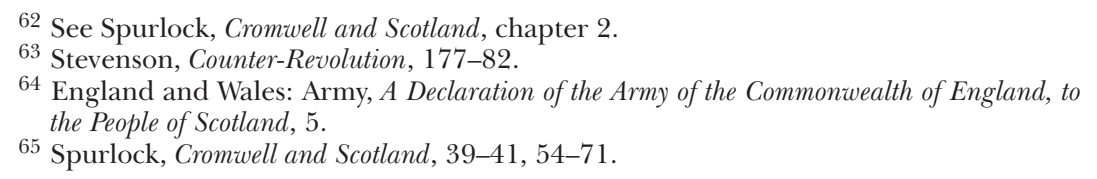


Since the Commonwealth believed its destiny rested in God's unfolding providence, news (both good and bad) represented an important element in deciphering the divine will. Whereas Scottish censorship to some extent represented a necessary means for maintaining unity within a static framework defined by the covenants, the Commonwealth adhered to an unrestricted view of unfolding providence leading to something new and predetermined but not yet realised. As such, the Commonwealth's approach to some extent heralded a departure from Scotland's still quasi-feudal structures. This necessitated a fairly free flow of truthful information-although that information need not be impartial-and changes to both the forum and the extent of debate.

In the run up to Dunbar Cromwell urged that the printed debates taking place between the English army and the Committee of Estates (and the Commissioners of the General Assembly) should be freely circulated among both English troops and the wider Scottish population: 'send,' he stated, 'as many of your papers as you please amongst ours, they have free passage, I feare them not; what is of God in them would it might be embraced and received'. ${ }^{66}$ This desire for the free distribution of polemics was shaped by a belief in providence and divine dispensation. The goal was to elicit compliance through conviction rather than coercion. ${ }^{67}$ The latter was only necessary if and when a people refused to see the clear providential judgments of God. Two brief examples of this attitude towards truth, revelation and culpability should be noted. According to John Morrill, the atrocity committed at Drogheda in 1649 could be interpreted as retribution against royalist soldiers who, by taking their fight to Ireland, had prolonged the effusion of blood in direct contradiction to the providential judgments delivered against Charles I in both of the English Civil wars. ${ }^{68}$ The refusal to interpret clear providential dispensations was regarded as belligerence and sin which required punishment. By contrast, those who sought to interpret the revelation of

66 Oliver Cromwell, A Letter Sent to the Generall Assembly of the Kirke of Scotland (London, 1650), 3. Cromwell thought the Scots treated the products of English presses less freely. He accused the Kirk, in particular, of censorship and slanderous propaganda similar to that demonstrated by Thomas Edwards' Gangraena: 'And by your hard and subtle words, you have begotten prejudice in those who do too much (in matters of conscience, wherin every soul is to answer for itself to God) depend upon you'. (Cromwell, A Letter Sent, 3-4; W. C. Abbott (ed.), The Writings and Speeches of Oliver Cromwell, 4 vols (Cambridge, MA, 1937-47), ii. 302; RCGA, iii. 21; Edinburgh, National Library of Scotland [NLS], Wodrow Collection, Wodrow Folio [Wod. Fol.], xxix (45).

67 Cromwell famously remarked of seditious material that if his government 'could not stand against paper shot, it was not worthy of preservation' (Jason Peacey, 'Cromwellian England: a propaganda state?', History 91 (2006) 176-99, at 184-5.

68 John Morrill, 'The Drogheda massacre in Cromwellian context', in David Edwards, Pádraig Lenihan and Clodagh Tait (eds), Age of Atrocity: Violent Death and Political Conflict in Ireland (Dublin, 2007), 258. This interpretation may also be applied to the subsequent massacres at Wexford and Dundee, in 1651. 
God were greatly respected by Cromwell, even if he did not agree with them, as demonstrated by the longstanding mutual respect between the Protector and George Fox. ${ }^{69}$

During the interregnum the only real restrictions placed on opinions were applied to those who strayed flagrantly into sedition or heresy and to those whose expression smacked of a belligerent refusal to respect providential guidance. Otherwise, the Commonwealth and Protectorate viewed the press as a primary tool for distributing information. Jason Peacey's argument - that interregnum governments used print to 'control the flow of information and opinion which reached both domestic and continental audiences' - is equally applicable to Scotland. ${ }^{70}$ Cromwell's conviction that Scotland could be convinced rather coerced rested on a generally held belief among his puritan counterparts, that most Scots were, as Arthur Williamson put it, 'latterday saints and a godly people. ${ }^{71}$ They shared a common faith, a common destiny and a similar place in history, all of which bestowed upon Scots a critical role in building God's new kingdom on earth. Cromwell and his republican colleagues believed that the Scots needed to be (and could be) convinced of their role in God's providential plan. Concerted efforts through print, proclamation and public dispute demonstrated 'the values to which the Republic sought to subscribe'. ${ }^{72}$ Many Scots accepted these arguments, as indicated by the compliance of individuals such as Alexander Jaffray, John Swinton and Sir James Hope of Hopetoun, as well as by Dumbarton and Dunbartonshire's enthusiastic embrace of the Tender of Union with England, if it meant participatory government 'without kinge and House of Lords under a free estate and Commonwealth'. ${ }^{73}$

By 1651 the English had no interest in utilising Scottish presses to print items for the English market. ${ }^{74}$ Instead, Scottish presses were now deployed to produce texts for distribution in Scotland. Evan Tyler's printing equipment was removed to the heavily garrisoned town of Leith sometime before mid-March 1651 and thereby brought more closely under the watchful eye of the Commonwealth regime: Leith would become the largest of England's citadels in Scotland and the most important hub from which the interregnum government operated in Scotland. The few surviving texts produced by the Leith press in 1650 and 1651 , before their control passed theoretically to the Commissioners for Scotland, were published with the explicit approval of the commander of Leith. For instance, the thoroughly anti-Kirk and

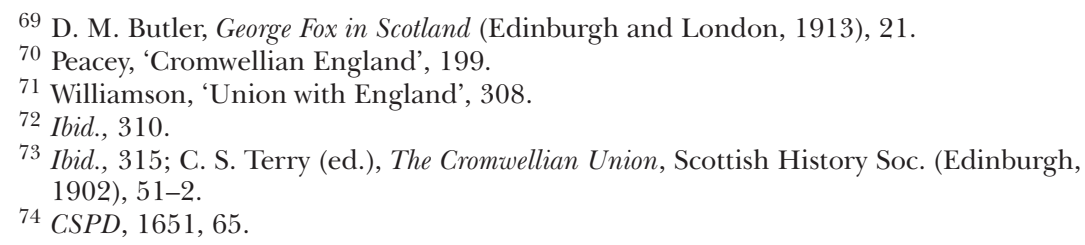


pseudo-Quaker work by Thomas Wood, A Dead-man's Testimony to the Church of Scotland, contained the approbation:

Having perused this Book, Intituled, The Dead-Mans Testament; I do finde it to be Orthodox and sound, and likewise usefull for the Lords People, namely, those to whom it is directed, I do therefore allow it forthwith to be Printed and Publishted. Given under my hand at Leith, Novemb. 25. 1651.

Timo[thy]. Wilks. ${ }^{75}$

Subsequent publications included official government pronouncements. When the Resolutioners declared their reasons for continuing to pray for the king in August 1653, the regime issued a long response which it 'prented, publifched, and fold [sold] in Edinburgh and uther pairtes of the countrey'. ${ }^{76}$ By 1656 printed ordinances abounded, 'quhairof great numberis ar ventit and fold [sold] in Edinburgh'.77 It was through such a publication that Wariston, a member of the Protectoral government, learnt of taxation to be levied on Scotland. ${ }^{78}$

Although the military administration initially exercised strict control over publication through the Evan Tyler press, the government monopoly of the press soon lapsed. Two of Edinburgh's other significant presses-Gideon Lithgow and The Heirs of George Anderson-were reactivated in 1652 and Andro Anderson began to print again in $1653 .^{79}$ This represented a relaxation of strict censorship and allowed James Guthrie to produce a defence of the Presbyterianism position on the role of elders in the church. ${ }^{80}$ Despite the freedom with which non-inflammatory Presbyterian works were now printed, the Commonwealth continued to undermine the religious monopoly of the Kirk through print. ${ }^{81}$ But even this policy gradually abated. The lull in royalist opposition (until Glencairn's rising in mid-1653) and

75 Thomas Wood, A Dead Man's Testament or A Letter Written to all the Saints of God in Scotland, Fellow-Heirs of the Blessing with those in England (Leith, 1651).

76 John Nicoll, A Diary of Public Transactions and Other Occurrences, Chiefly in Scotland, 1650-1667, ed. David Laing, Bannatyne Club (Edinburgh, 1836), 111.

77 Ibid., 161 .

78 Sir Archibald Johnston of Wariston, Diary of Sir Archibald Johnston of Wariston, ed. D. H. Fleming and J. D. Ogilvie, Scottish History Soc., 3 vols (Edinburgh, 1919-40), iii. 21.

79 The following works were published by Gideon Lithgow: The Psalms of David in Meeter (Edinburgh, 1652); and by The Heirs of George Anderson: A Representation of the Sad Condition and Humble Desires of the People of Glasgow (Edinburgh, 1652); Westminster Assembly, The Confession of Faith, and the Larger and Shorter Catechisms First Agreed upon by the Assembly of Divines at Westminster, and Now Appointed by the Generall Assembly of the Kirk of Scotland, to be a Part of Uniformity in Religion Between the Kirks of Christ in the Three Kingdomes (Edinburgh, 1652); C. Irvino, Bellum Grammaticale, ad exemplar Mri. Alexandri Humii, in gratiam eorum, qui Amoniores Musas venerantur (Edinburgh, 1652).

${ }^{80}$ James Guthrie, A Treatise of Ruling Elders and Deacon (Edinburgh, 1652). While censorship began to lessen, it was not excessively loose. Guthrie's work was published without an imprint by the printer, perhaps a sign that times were tense.

81 For detailed discussion of early publishing policies against the Kirk, see Spurlock, Cromwell and Scotland, chapter 3. 
a network of, at their height, over sixty garrisons accompanied more moderate policies and attempts to engender religious unity in order to further Commonwealth principles. Yet, while settled government began to alleviate fears on both sides of the Independent-Presbyterian divide, the credibility of the government came under scrutiny after Cromwell's acceptance of the Protectorate in December 1653. Several pieces were published in Scotland, as elsewhere in Britain and Ireland, defending the role of the Protector against accusations of a return to monarchy. ${ }^{82}$ The greatest criticism came from religious and political radicals such as the Fifth Monarchists who had once formed the bedrock of support for the Commonwealth. Cromwell sought to allay fears by reemphasising his position on toleration. Here, the distinction between press ownership and government policy became slightly clearer. The Stationers' Company, like the first Protectoral parliament, differed from Cromwell over to how to deal with disgruntled radicals. Rather than courting Baptist, Quaker and Fifth Monarchist favour, the Company decided that stability depended upon orthodoxy and so it sided with London's Presbyterians and the Protectoral parliament in denouncing sects. ${ }^{83}$ In Scotland the Company's press followed suit, attacking heretics, and particularly the Quakers, who promoted personal liberty over social stability. It also encouraged publication of works which advocated orthodox theology. This may account for the timing of Evan Tyler's London republication of Robert Baillie's Disswasive from the Errors of the Time in 1655. While printings of this period do not include the official approbations appearing in endorsed works issued during martial rule, the moderate tone of the press would hardly have irritated either General Monck, appointed commander of the forces in Scotland in April 1653, or the religiously moderate Commissioners for Scotland, appointed in 1652 .

Although Scotland's presses continued to print Protester and Resolutioner works, they were few in number until after Cromwell's death and no longer part of a concerted government policy to undermine Scottish Presbyterianism. This may have been partly because of the moderate religious policies towards Scottish Presbyterians - and the Resolutioners in particular-pursued during Lord Broghill's presidency of the Council of Scotland, from September 1655 to August 1656. ${ }^{84}$ At any rate, the mid-1650s were marked by the production

${ }^{82}$ According to a contemporary English journal, in 1654 the regime re-printed John Goodwin's Synkretismos which constituted an appeal to accept the change in government ('Diurnal of Occurences in Scotland', in James Maidment (ed.), The Spottiswoode Micellany, Spottiswoode Soc. (Edinburgh, 1845), ii. 174). See too John Goodwin, Synkretismos: or Dis-satisfaction Satisfied. In seventeen sober and serious queries ... (London, 1653); Marchamont Nedham, A true state of the case of the Commonwealth of England, Scotland and Ireland, and the dominions thereto belonging; In reference to the late established government by a Protector and a Parliament. (London, 1653), which was reprinted in Leith.

83 D. L. Smith, 'Oliver Cromwell, the first protectoral parliament and religious reform', in D. L. Smith (ed.), Cromwell and the Interregnum (Oxford, 2003), 176.

${ }^{84}$ Little, Lord Broghill, 91-123. 
of sectarian publications. From 1655 to 1657 Edinburgh's presses produced several anti-Quaker tracts composed by English authors. ${ }^{85}$ These works, along with the regime's treatment of Quakers, elicited Quaker responses and apologetics. ${ }^{86}$ The relaxation of press controls after Cromwell became Protector even witnessed the publication of a tract that some historians have billed as a Roman Catholic apologetic, although it was in fact a Quaker piece. ${ }^{87}$ Despite the presbytery of Jedburgh's complaints about the printing of 'sinfull Literyes', Scotland's presses remained largely free of contentious religious texts from 1655 until the Protector's death in September 1658, except for the few directed against Catholics and Quakers.

What was, and what was not, strictly censored depended on the wider political situation. Presbyterian works venting against toleration or Independency were not granted access to the press in the early years of the regime. There were regular reports during periods of Baptist and Fifth Monarchist dissatisfaction of searches undertaken for seditious materials. ${ }^{88}$ Yet this censorship was neither as strict nor as consistently enforced as that by the Covenanters in the previous decade. During the interregnum not only did a wider variety of Protestant books circulate than ever before, but even Roman Catholic books seem to have been more readily available. Andrew Hay of Craignethan, for example, mentioned the arrival of two bales of Catholic books. ${ }^{89}$ Hay, an elder in the parish of Biggar who served on the presbytery of Lanark, felt little need to ensure that the books were handed over to either the English or Kirk authorities. Indeed, he noted in his diary on 5 October 1659 -during a period of growing political uncertainty and intrigue - that he had visited a bookbinder to have his 'french printed Scots catholick [book] bound' ${ }^{90}$ Hay's account of his personal devotion, his involvement in censuring wayward parishioners and the persistent renewal of his own personal covenant with God indicate that he was a fervent Presbyterian-but he nonetheless felt free during the interregnum to read previously abhorred texts. ${ }^{91}$

${ }^{85}$ John Gilpin, The Quakers Shaken, or, A Discovery of the Errours of That Sect (Edinburgh, 1655); John Stalham, Contradictions of the Quakers (so Called) to the Scriptures of God (Edinburgh, 1655); James Brown, Antichrist (in Spirit) Unmasked (Edinburgh, 1657).

86 Jonas Dell, Forms the Pillars of Antichrist (London, 1656); Francis Howgill, To All You Commanders and Officers of the Army (Leith, 1657).

${ }^{87}$ Love the Precious Ointment, That Flowes Down from the Head Christ Jesus, to All His Members; and Makes Them Dwell Together in Unity (Leith, 1654). This was originally printed in London and then reprinted in Leith.

88 In 1655: Nicoll, Diary, 145; in 1659: NLS, Adv. Ms. 35.5.11, fos 62-4, 79, 83.

89 A. G. Reid (ed.), The Diary of Andrew Hay of Craignethan, Scottish History Soc. (Edinburgh, 1901), 67, 87. A bale comprised ten reams $(4,800)$ of sheets, so two bales amounted to nearly 10,000 pages

${ }^{90} \mathrm{Ibid} ., 153$.

${ }^{91}$ Hay's diary from May 1659 to January 1660 provides a record of his regular attendance at sermons, his devotional reading and on no less than eight occasions the renewal or 'renovation' of his personal covenant with God (Ibid., 31, 37, 51, 82, $106,119,120)$ 
While the rigidity of censorship declined and the diversity of available publications grew, at no point was printing in Scotland completely free of control. A committee of parliament met in October 1653 to mull over 'what measures are fit for suppressing scandalous pamphlets' throughout the Commonwealth. One of its five members was Sir James Hope of Hopetoun. ${ }^{92}$ His inclusion may suggest that Scotland witnessed the publication of scandalous material or that Hope possessed useful experience of successful and draconian censorship, as had been applied by the Scottish Covenanters. Then, in April 1654, Cromwell wrote to Monck, authorising him 'to make use of and Command any press or presses there, for printing and publishing any proclamacions, Declaracions, Orders, bookes, or other matters which you shall thinke fit for the publique service, and to prohibite the use thereof by any person or persons in any cases where you shall see cause'.$^{93}$ The following year these instructions were repeated verbatim to the newly formed council in Scotland. ${ }^{94}$ At about this time James Brown began to print again in Aberdeen, the bulk of his work comprising re-publications of government proclamations. The grant issued in favour of the university of Glasgow, in 1657, to print whatever was needed for teaching, prompted the relocation in the same year of The Heirs of George Anderson to Glasgow. Thus, despite restrictions, the print industry showed signs of growth following Cromwell's instructions - and the impact of this policy extended beyond those immediately involved in the printing industry.

The increasing amount of printed material had a profound impact on Scotland. In 1655 John Nicoll recorded that printed papers were 'daylie ventit and fauld [sold] throw the cheifeft tounes and citeis of Scotland, ${ }^{95}$ This marked a distinct cultural shift. Print culture, already firmly established and thriving in England, had now arrived in Scotland. ${ }^{96}$ Mann noted two particular aspects that signposted the change. First, he lamented that the primary product of Scotland's presses prior to 1660 'were taken up with official church and government declarations, short justifications and replies in the politico-religious debates of the time, early news-sheets, other single-sheet ephemera and some printings of scripture ${ }^{97}$ Second, he noted that the total production and consumption of printed material produced during the 1650s never dropped below the average of the previous four decades. In fact, in areas beyond Edinburgh, particularly in 'provincial centres', the number

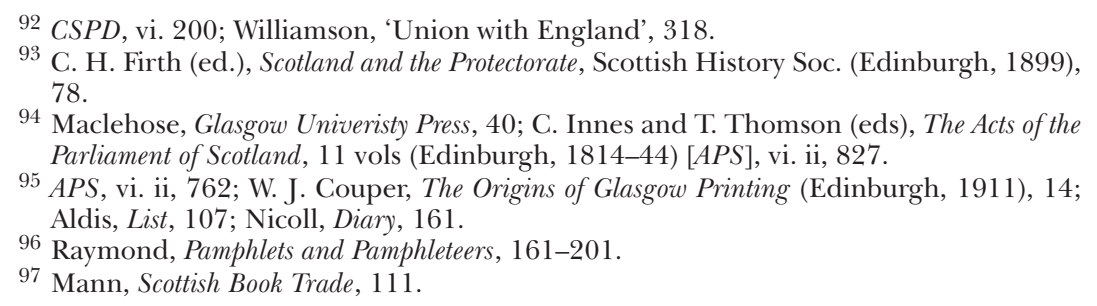


of booksellers and bookbinders increased and, as Mann noted, 'the 1650 s marked the start of expansion for small booksellers'. ${ }^{98}$ As already noted, Nicoll had observed and recorded this development in his diary. It is all the more important since the expansion of the book trade occurred in a period of economic decline, largely caused by the cost of funding the Covenanting military operations during the previous decade. ${ }^{99}$ Sales remained buoyant because Scotland's presses were producing declarations, debates and news that engaged the subjugated population of Scotland in a time of turbulent political change. While the production of privately motivated, traditional theological works and official Kirk declarations dwindled from the robust output of the 1640 s, their place on the presses had been taken by smaller, cheaper and more reader-friendly pieces addressing immediate circumstances and aimed at the wider public. The English brought new ideas about the purpose to which the printing press could be put which were more akin to the culture of multi-confessional, sixteenth-century Germany than to the existing print culture of Presbyterian Scotland from 1638. As Williamson and Raymond have argued, Scotland's printing industry had long focused on a non-Scottish market. The new approach had been honed over the previous decade when English presses had produced popular, polemical, reader-friendly pieces designed to influence public opinion. The interregnum regime introduced and sustained the practice of using Scottish presses for such purposes.

The divergence between these approaches to printing was encapsulated in the exchange between the English chaplain Nicholas Lockyer and the Scottish minister James Wood, who seems to have been appointed as the semi-official polemicist for the Resolutioner party. When Lockyer attacked the composition and structure of the Kirk, and even the nation's devotion to it, his medium was a short, compact and easily digestible, pocket-sized book of only 138 pages, the core of which had originally been delivered as a sermon. ${ }^{100}$ Wood's response took over

98 Mann, Scottish Book Trade, 31, 232. Aldis, List, 105-6, 113, 183 notes that the following booksellers opened during the interregnum: in Glasgow, R. Sandersone (1654), J. Falconer (1659), J. Morisone (1659) and M. Paterson (1659); in St Andrews, G. Dradoun (1654); in Edinburgh, James Glen (1656); in Perth, George Dickson (1653); in Aberdeen, D. Stranghan [Straughan] (1659). This list is not exhaustive as many booksellers are only known because of debts left at their death. Nor did booksellers necessarily begin trade on these dates. Morisone, for instance, seems to have been active earlier in the decade, at least as an apprentice.

${ }^{99}$ High levels of taxes were introduced during the 1640 s to pay for Scottish armies. According to one contemporary source these taxes were particularly high on foodstuffs (NLS, Wod. Fol., xxxi (37)). For a discussion of the knock-on financial implications of Scotland's involvement in the Wars of the Three Kingdoms, see L. A. M. Stewart, Urban Politics and the British Civil Wars: Edinburgh, 1617-1653 (Leiden, 2006)

100 Nicholas Lockyer, A Litle Stone Out of the Mountain. Church-Order Briefly Opened (Leith, 1652). The volume measures approx. $8 \mathrm{~cm} \times 5 \mathrm{~cm}$. 
two years to complete and comprised 386 octavo pages. ${ }^{101}$ A second example can be seen in James Durham's A Dying Man's Testament to the Church of Scotland (Edinburgh, 1659). Though its coverage extended beyond a rebuttal of Thomas Wood's sixteen-page attack on the Kirk, published in 1651, Durham made reference to Wood's pamphlet in the title of his 492-page book. ${ }^{102}$ Although like-minded and educated Presbyterians, such as Archibald Johnston of Wariston, might take time to read them, the sheer length of these works by Durham and Wood probably meant that the average non-university educated Scot did not. ${ }^{103}$ Meanwhile, political material, debate and news found a ready audience. The print culture of interregnum Scotland was summed up in James Wood's lament:

What the wise observing King uttered long agoe, that of making of Books there is no end, was never more verified in any then it is in the present age wherein, scribunt docti indoctique, every smatterer and every fancie-full head must have the Presse travel to bring forth their froathy conceptions: And Presses by many are made use of as engines to discharge revylings, reproaches, and blasphemies against the God of Heaven, his blessed Truths, wayes and Ordinances. ${ }^{104}$

Wood loathed the content of these publications but he affirmed a growth in the volume of production. His upset at these developments was perhaps caused by the gathering pace of popularity and consumption for such material.

Domestic productions were supplemented by material produced beyond Scotland's borders, often in the Low Countries. This was not new but more limited censorship encouraged greater foreign imports. The growing demand for all types of printed matter was also reflected in the distribution of illicit texts. ${ }^{105}$ Meanwhile, commanders in Scotland requested that particular ideological texts be printed as aids in their attempt to persuade the Scots of the positive aspects of Commonwealth principles. Robert Lilburne, for instance, sought to circulate sermons by John Owen so that the Scots might be more 'truly informed concerning our [English Army's] proceedings'. ${ }^{106}$ The growing availability of published materials prompted Andrew Hay of Craignethan to record on 14 November 1659 that a trip to the stationers

101 James Wood, A Little Stone Pretended to be Out of the Mountain, Tried and Found to be Counterfeit (Edinburgh, 1654). For Wood as a polemicist for the Resolutioners, see Spurlock, Cromwell and Scotland, 93, 217n

102 Thomas Wood, A Dead Man's Testament: or, A Letter Written to all the Saints of God in Scotland, Fellow-Heirs of the Blessing with those in England (Leith, 1651).

103 Wariston, Diary, ii. 232-3.

104 From Wood's dedication to John Kennedy, sixth earl of Cassilis, in Wood, A Little Stone, ded. 2.

105 Firth, Scotland and the Protectorate, 213, 238; NLS, Adv. Ms. 35.5.11, fos 62-4, 79, 83

106 J. Nickolls (ed.), The Original Letters and State Papers of State, Addressed to Oliver Cromwell (London, 1743), 48; Anne Laurence, Parliamentary Army Chaplains, 1642-1651 (London, 1990), 71-2. 
to collect David Ferguson's new book of Scottish proverbs turned into perusing 'som other books about an hour'. ${ }^{107}$ In his diary Wariston too referred to a large number of English texts, several of which had only recently been published in London. ${ }^{108}$ On one occasion he saw a recent publication by the Englishman John Biscoe on his friend John Lawson's table. Upon Lawson's recommendation, Wariston 'sent [?a servant] to search for the book' in order to procure a copy for himself. ${ }^{109}$ The implication is that the book could be found at the local booksellers. Yet, perhaps more important still than the variety and availability of texts was the novel distribution of news in the form of newsbooks and journals - the introduction, in other words, of the newspaper.

The interregnum represented the first period in which newspapers were regularly printed in Scotland. Within months of the English arrival in Edinburgh Scotland's first multi-issue newspaper appeared. Entitled Mercurius Scoticus, it was produced from 22 July 1651 until 13 January 1652. ${ }^{110}$ Although subtitled 'The Royal Messenger' it was not of royalist sympathies but sought instead to satiate the desires of 'many Forreigne expectants eyes' and the English soldiers in Scotland who desired to be kept abreast of news from England and Ireland. ${ }^{111}$ Although the order to cease print of journals in 1652 ended the run of the Leith-based Mercurius Scoticus, its market was soon assumed by reprinted London-based newspapers. ${ }^{112}$ On 15 March 1652, two months after the silencing of Mercurius Scoticus, the London-based A Diurnal of some Passages and Occurrences began to be re-printed at Leith. ${ }^{113}$ From June 1653 Mercurius Politicus was also re-printed in Leith. ${ }^{114}$ These papers maintained a pro-government slant in return for inside information, which allowed them to provide 'breaking news'. Both the newspapers and the government arguably profited from

107 Reid, Andrew Hay, 189.

108 Wariston, Diary, iii. 30-2.

109 Ibid., iii. 24.

110 J. C. Irons, Leith and its Antiquities, 2 vols (Edinburgh, 1897), ii. 122. David Stevenson has noted that the first newspaper printed in Scotland appeared on 16 August 1648 but that only one issue was produced (Stevenson, 'Revolutionary regime', 332).

111 C. H. Firth (ed.), Scotland and the Commonwealth, Scottish History Soc.(Edinburgh, 1895), 316; Mercurius Scoticus, 22-30 July 1651.

112 Mann and others have inaccurately identified this work as a royalist journal (Mann, Scottish Book Trade, 174). In reality, 'The Royal Messenger' was a 'catchword' 'likely to sell it at once to a rovalist... Its contents are anything but royalist in matter or manner and they consist mainly of fulsome praise' for the Commonwealth and its military triumphs (J. B. Williams, A History of English Journalism (London, 1908), 142).

113 Carolyn Nelson and Matthew Seccombe, British Newspapers and Periodicals, 1641-1700 (New York, 1987), 56. The journal was re-printed in Leith from 15 March 1652 until 4 January 1653.

114 Printing of Mercurius Politicus moved to Edinburgh in 1654. It appeared until 11 April 1660, when its name was changed to Mercurius Publicus. (Ibid., 242). George Chalmers and others have incorrectly dated publication from October 1653 (Chalmers, Life of Thomas Ruddiman, 117). 
this arrangement. ${ }^{115}$ Meanwhile, the censure of Mercurius Scoticus had little impact on its printer, latterly probably Christopher Higgins, who continued to reprint the government approved London papers. While some lamented in 1654 that 'what the world abroad is doing we know no more than the London diurnal tells us', a steadier flow of information was available than ever before. ${ }^{116}$ On several occasions Archibald Johnston of Wariston mentioned that he made recourse to both London and Scottish editions of the journals to keep abreast of current affairs. Reading the news appears to have become a fundamental part of his routine. ${ }^{117}$ Similarly, Andrew Hay reported that on a Saturday morning he went 'to... [his] horse and bought the newes printed here'. He too noted differences in local editions which 'contradicted the London Diurnell'. ${ }^{118}$ Journals did not control information; but they placed Scottish citizens within a broader political context which allowed for political discourse and debate not possible under the Covenanters. And although Robert Baillie, while in London, had sent newsbooks back to Scotland, along with his reports on the Westminster Assembly for the General Assembly, no similar conduit of information had existed in Scotland before the interregnum. ${ }^{119}$

The introduction of news prints under the Commonwealth had quickly created a market for news in Scotland which permanently transformed Scottish culture. The shift from oral rumour to news in print had a profound cultural impact as printed 'facts' made tracts objects of value and power, in Scotland and beyond. The significance which the printed word came to represent in interregnum Scotland is indicated by an entry in Sir James Hope of Hopetoun's diary. He recorded a dream in which God had sent Hope a message in the format of 'a printed paper lyke ane Act or proclamatione'. ${ }^{120}$ Hope's account of the authoritative value of the printed word is particularly valuable for revealing the impact of new forms of popular and widelyavailable print. In the English context, Raymond has argued that 'the newsbook emerged out of other forms of print and its reception was

115 For an explanation of the symbiotic relationship between the interregnum government and the news journals, see M. J. Seymour, 'Pro-government Propaganda in Interregnum England, 1649-60', unpublished Ph.D. thesis (University of Cambridge, 1987), 60, 408. More recently Jason Peacey has argued that government officials were closely involved in providing the information used by these periodicals (Peacey, 'Cromwellian England', 190-8). The argument here rests less on where the information came from and more on how it was circulated.

116 Baillie, Letters and Journals, iii. 256; Peacey, 'Cromwellian England', 198. Peacey has suggested similar feelings were expressed in Ireland.

117 Wariston, Diary, ii. 118, 137, 155, 214, 312.

118 Reid, Andrew Hay, 204

119 Baillie, Letters and Journals, ii. 171, 182, 195, 220, 231, 243, 246, 289, 324, 369; Joad Raymond, The Invention of the Newspaper: English Newsbooks, 1641-1649 (Oxford, 1996), 240, 249, 260.

120 J. B. Paul (ed.), 'The diary of Sir James Hope, 1646-54', Miscellany of the Scottish History Society, vol. iii (Edinburgh, 1919), 156. 
partly governed by the same'. ${ }^{121}$ Previously in Scotland printed material had often been concerned with legislative matters and the authority which such material carried was, to some extent, inherited by the new forms of printed material. News journals carried weight similar to letters written by eyewitnesses but they possessed far greater currency than hearsay. According to several intercepted royalist letters, exiles regarded newspapers as the primary source of information for events in Scotland, providing 'our constant and most perticular intelligence'. ${ }^{122}$ Circulating information in this way became so inculcated during the decade that the Aberdeen town council initiated its own 'weekly diurnall to be sellit for the wse of the inhabitants' in July $1657 .{ }^{123}$ During the interregnum demand had developed for news.

In assessing the enduring impact of the interregnum on Scotland's engagement with the printing press several factors must be taken into account. First, Arthur Williamson has demonstrated that late-sixteenth and early-seventeenth century Scotland's print culture did not develop around a domestic focus. Instead, the Presbyterian intelligentsia invested its energies 'into the intellectual world of the continent' by writing in Latin. ${ }^{124}$ Second, once Scottish publications did appear in the vernacular they were designed for a foreign market, in England. From as early as 1640 Scottish Covenanters had produced justifications for their invasion of England during the Bishops' Wars. In the mid1640s-despite censoring publications imported into Scotland-they had even established a newspaper in London, intended to win foreign support for their covenanted experiment. ${ }^{125}$ Third, during the interregnum a variety of papers promoting (for Scotland) new and diverse ideas came off Scotland's presses and a print culture similar to that already evident in England emerged in Scotland. Fourth, this did not change after the Commissioners for Scotland imposed censorship in January 1652 or after Cromwell, followed by his son Richard in 1658, granted the authorities in Scotland the power to establish and prohibit presses under their own authority. ${ }^{126}$ Finally, and most significantly, the introduction of serial newspapers provided the general public with a previously unknown degree of information. The impact of this innovation should not be underestimated.

121 Raymond, Invention, 184.

122 Firth, Scotland and the Commonwealth, 251; similar claims are also found in Firth, Scotland and the Protectorate, 207, 231.

123 John Stuart (ed.), Extracts from the Council Register of the Burgh of Aberdeen, 1625-1747, 2 vols (Edinburgh, 1871-2), ii. 165-6; John Stuart (ed.), The Miscellany of the Spalding Club, 5 vols (Aberdeen, 1841-52), v. 181; Williamson, 'Scotland: international politics', 208.

124 Williamson, 'Scotland: international politics', 214-15.

${ }^{125}$ For a brief account of the newspaper The Scottish Dove, see ibid., 202, 205-13; Raymond, Invention, 34-5.

126 Maclehose, Glasgow University Press, 40; APS, 1648-1660, vi. ii, 763, 827, 876; Mann, Scottish Book Trade, 146. 
With the appearance of Commonwealth newspapers Scots could read reports from Scotland, England, Ireland and the continent. Accounts of the massacre of Protestants in Piedmont in 1655 mingled with tales from the Caribbean of military encounters with the Spanish. Even domestic reports were important, as they opened Scottish practices to scrutiny and challenge. It was, for instance, the journals which advanced the first significant domestic criticism of approaches to witch hunting. Moreover, although the presses of the Stationers' Company in Leith were responsible for reproducing the newspapers in circulation, these were not the only presses operating during the 1650s. Government had no monopoly over printing and its controls were not applied in a draconian fashion. Non-English-controlled presses were allowed to print and the Stationers' Company presses did not always follow the disposition of the regime. This was why the Commonwealth government reserved the right to meddle in print, though it did so in an impromptu and flexible fashion rather than through rigid legislation like that applicable in England. ${ }^{127}$ The functionality of the press in Scotland was not diminished during the interregnum; on the contrary, it experienced a renaissance. It was the changing context, use and output of interregnum printing, rather than just its content, that stimulated 'a regular engagement with the minutiae of book culture'; and this continued to have an impact after the interregnum. ${ }^{128}$ Scotland's first domestic multi-issue news journal commenced publication in 1661 in a time of political tension; ${ }^{129}$ and Charles II's Restoration required a fresh approach to censorship because Scots were now use to accessing greater quantities and varieties of information than they had ever done before the interregnum.

\footnotetext{
${ }^{127}$ For the role of the Stationers' Company in enforcing censorship, see Jason McElligott, 'A couple of hundred squabbling small tradesmen'? Censorship, the Stationers' Company and the state in early modern England', in Joad Raymond (ed.), News Networks in Seventeenth-Century Britain and Europe (London, 2006), 85-102.

128 Mann, Scottish Book Trade, 30.

${ }^{129}$ Williamson, 'Scotland: international politics', 202.
} 